\title{
Book Review: The Real Cost of Fracking: How America's Shale Gas Boom Is Threatening Our Families, Pets, and Food
}

\author{
Miriam R Aczel * \\ Centre for Environmental Policy, Imperial College London, London, UK
}

Keywords: hydraulic fracturing, shale gas, precautionary principle, environmental exposure, toxicology of pollutants

\author{
A Book Review on \\ The Real Cost of Fracking: How America's Shale Gas Boom is Threatening Our Families, Pets, \\ and Food
}

\section{OPEN ACCESS}

Edited by:

Mahnaz Mazaheri Assadi, Iranian Research Organization for Science and Technology, Iran

Reviewed by:

Mahnaz Mazaheri Assadi, Iranian Research Organization for

Science and Technology, Iran Robert Canales,

University of Arizona, USA

${ }^{\star}$ Correspondence: Miriam R. Acze miriam.aczel14@imperial.ac.uk

Specialty section: This article was submitted to Environmental Health,

a section of the journal

Frontiers in Environmental Science

Received: 13 February 2017 Accepted: 12 April 2017 Published: 28 April 2017

Citation: Aczel MR (2017) Book Review: The Real Cost of Fracking: How America's Shale Gas Boom Is Threatening Our

Families, Pets, and Food.

Front. Environ. Sci. 5:17. doi: 10.3389/fenvs.2017.00017
Michelle Bamberger and Robert Oswald (Boston, MA: Beacon Press Books), 2014, 248 pages, ISBN-10: 0807081418; ISBN-13: 978-0807081419.

The Real Cost of Fracking by Michelle Bamberger and Robert Oswald examines the impacts and risks of hydraulic fracturing and shale gas extraction on our environment and health, food supply, and pets. Written by a veterinarian and a pharmacologist, the book combines scientific studies and data with anecdotal experiences to make a strong case that individuals and communities are at risk.

The authors describe how they began to investigate the impacts of hydraulic fracking because many of their neighbors in upstate New York had leased their property to drilling companies. The issue was contentious in the community. In the course of their research, they heard from many individuals about the effects of gas drilling on the health and well-being of their animals and families, and felt that these voices should be heard.

Highly readable and well-organized, the book is divided into three sections: families and their pets; fracking, farming, and our food supply; and environmental justice. In interviews included in each section, families living in areas with shale gas activities describe the wide-ranging impacts on their lives. A thoughtful epilog asks the question: "Where do we go from here?" and provides some steps that we can take to protect our health.

The introduction discusses the precautionary principle, which requires exercise of caution in the absence of data to conclusive show the safety of an activity, such as fracking. The authors say that the industry follows the reverse: fracking can proceed, unless there is definitive proof that it causes harm, thus "...putting the burden of proof on the victim" (p. 9).

Much of the book's emphasis is on impacts to animals and children, "inadvertent sentinels" for risks from environmental pollutants due to "their higher metabolic rates and immature neurologic and detoxifying systems" (p. 10). The first chapter explains that animals are even more vulnerable than children as they remain at home or outside, thus "increasing exposure times" (p. 19), and most families cannot afford alternative water or food supplies for their animals to replace a contaminated source.

The second section deals with the impacts of fracking on farming and our food supply, and questions the "safety of food raised near such operations" (p. 97). Gas wells and the extraction activities are often intermixed with food production processes. The authors discuss the toxic 
chemicals and radioactive compounds from drilling waste, volatile organic compounds, and other hazards, and because animals are usually slaughtered before chemical testing, conclude that that "we really don't know" (p. 101) whether our food and water are safe.

The third section deals with issues of environmental justice and shows the difficulty in gaining recourse after environmental damage or harm to health has occurred. The stories recount how "drilling has pitted neighbor against neighbor" (p. 153). But while that may be true in some locations, the authors describe a small community where "we experienced a different dynamic, one that provides hope and inspiration" (p. 153) as neighbors pulled together to supply one another with water as they faced problems of contaminated water, and inadequate help from government or industry.

The overarching message of the book is that the stunning lack of information on multiple levels makes decision-making virtually impossible. For example, settlements of lawsuits involving health impacts typically include non-disclosure agreement requirements. Thus, a veterinarian may suspect an animal has encountered a contaminant, but the practitioner has no right to information on the suspected chemical. Not only is there no transparency, there is no recourse. While there is a lack of data on multiple levels, the anecdotal data and interviews shows that there is indeed danger-people and animals are getting sick-and we need to act. The epilog addresses what next steps are necessary, including collection of longer term data and lifecycle assessments of the fracking process, and the need for better regulation: "the solution is better regulations and better enforcement of unconventional fossil fuel extraction in the states that allow this process" (p. 180).

It is significant to note that the key messages embedded in this work are in line with the Food and Agriculture Organization of the United Nations' Sustainable Development Goals, a list of 17 universally-relevant goals "integrating the three dimensions of sustainability-social, economic and environmental ${ }^{1}$." In particular, the seventh goal of "affordable and clean energy"

${ }^{1}$ United Nations http://www.fao.org/sustainable-development-goals/goals/en/ explains that "food systems, which currently consume 30 percent of the world's energy, will gradually need to decouple from fossil fuel dependence to deliver more food with less and cleaner energy ${ }^{2}$." Additionally, goal six discusses increasing food production while using less water. This is import to highlight as we consider the demonstrably large water quantities required for unconventional gas extraction. In a similar vein to the Sustainable Development Goals, Bamberger and Oswald's work sheds light on the complexity of the food-energy-water nexus, and shows how the specific impacts of hydraulic fracturing affect our food and water sources, the health of our families, and our agricultural systems and animal health.

Bamberger and Oswald provide a novel and groundbreaking examination of the effects of fracking on those who cannot speak for themselves, our farm and household animals, who act as the "canaries in the coal mine." The authors reach the disturbing conclusion that despite common assertions to the contrary, there is indeed evidence of direct links between unconventional drilling and health problems. The dangers are made that much more immediate through the telling of real stories of loss and harm. This extremely important work should be read by anyone who is interested in the effects of unconventional gas extraction on our families and animals, food supply, and environment.

\section{AUTHOR CONTRIBUTIONS}

The author confirms being the sole contributor of this work and approved it for publication.

Conflict of Interest Statement: The author declares that the research was conducted in the absence of any commercial or financial relationships that could be construed as a potential conflict of interest.

Copyright (c) 2017 Aczel. This is an open-access article distributed under the terms of the Creative Commons Attribution License (CC BY). The use, distribution or reproduction in other forums is permitted, provided the original author (s) or licensor are credited and that the original publication in this journal is cited, in accordance with accepted academic practice. No use, distribution or reproduction is permitted which does not comply with these terms.

${ }^{2}$ www.fao.org/3/a-i4997e.pdf 